\title{
Higher Education Drop-Out in Spain-Particular Case of Universities in Galicia
}

\author{
Maria Elena Arce ${ }^{1}$, Barbara Crespo ${ }^{2} \&$ Carla Míguez-Álvarez ${ }^{2}$ \\ ${ }^{1}$ Defense University Center at Spanish Naval Academy, Marín, Spain \\ ${ }^{2}$ University of Vigo, Vigo, Spain \\ Correspondence: Maria Elena Arce, Defense University Center at Spanish Naval Academy, Escuela Naval \\ Militar, Plaza de España, 2, 36920 Marín, Spain. Tel: 34-986-804-900. E-mail: elena.arce@cud.uvigo.es
}

\author{
Received: December 23, 2014 Accepted: January 23, 2015 Online Published: April 29, 2015 \\ doi:10.5539/ies.v8n5p247 \\ URL: http://dx.doi.org/10.5539/ies.v8n5p247
}

\begin{abstract}
The existence of a high university dropout rate in Spain is undeniable. Data shows that approximately one out of five students drop out from college. During the economic expansion period (2001-2007) more students abandoned their studies than during the crisis period (2007-2011). This situation also affects unemployment rates due to the fact that higher education leads to lower unemployment rates. Galicia presented slightly higher dropout rates than Spain from 2006 to 2009; nevertheless during the 2009/2010 academic year this rate was lower. The reasons for dropout can be divided into six distinct factors: psycho educational, evolutionary, family, economic, institutional and social factors. The main drop-out motives are related, among others, to incompatibility with work, economy, university (environment, teachers and difficulties) and so on. According to the BBVA research, the dropout rate imposes a great cost on the entire economy reaching the sum of 5,772 euros per year and per student and exceeding the amount of 1,500 million euros if the student drops out during the first cycle. Due to the urgent need of reducing the dropout rate, the Ministry of Education developed an action plan to increase the number of young people enrolled in a higher education course; so that, consequently, Spain can redirect its economic growth model.
\end{abstract}

Keywords: dropout, students, higher education, socio-economic environment

\section{Introduction}

Education is one of the five priority objectives in the new European strategy, becoming one of the engines for economic growth and employment. The European Council has quantified a series of goals in order to improve the education levels in the year 2020. These goals pretend to reduce the dropout rate as well as to increment the population percentage between 30 and 34 years that complete third level education. In the case of Spain, the dropout reduction has been fixed at $15 \%$ for 2020 and it was established a 2020 national target of $44 \%$ for the tertiary attainment rate.

Several indicators try to study the causes of academic failure in Spain, especially in higher education at universities. Nowadays, this topic acquires an important relevance due to the high dropout rates that should be studied in order to reduce them. The dropout phenomenon is a parameter difficult to assess because of the lack of information and data from the students after they have left their studies. However, the study of this topic is currently being introduced in different reports that allow us to extract important conclusions that must be taken into account in the decision making of the university policy. In addition, the provisional data shows that the percentage of students that drop out from college is smaller compared to previous years and a slight decline is expected in coming years (fact that is directly related to the reduction of the population between 18 and 24 years old.) This trend is more prevalent in engineering and architecture students, degrees that in the last ten years have lost one out of four students. It is also significant and alarming the decrease in the science branch. Particularly, in Galicia the rate of students that enroll in higher education during the last ten years presents was reduced to almost $30 \%$. The evaluation of certain university indicators frequently used, such as performance, success and evaluation rates, are linked to enrolled, presented and passed credits. Therefore, the analysis of these available data is relative simple because it only takes into account those students who continue or have finished their studies. However, from recent years it has been considered important to study other indicators that take into account those students who start but who do not continue their academic career. This has led to the current 
research on the dropout rate. Spanish institutions and researchers try to quantify this rate as well as to investigate about the possible causes of this phenomenon.

One of the first definitions of dropout is given in 1982 by Tinto (1982): "a student voluntary drop out is anyone who withdraws from the institution without completing the academic program in which the student was enrolled". During these years, diverse investigations related to dropout rates have been carried out. The first Spanish studies addressing this topic date from 1968. In another paper, Tinto (Tinto \& Asociación Nacional de Universidades e Instituciones de Educación Superior (México), 1987) developed a statistical research which reflects the difference between enrolled students and graduated students since 1963 to 1965 in technical colleges from Madrid. Other works from 1970 to 1992 continue this trend of study, such as (Bendito \& Altamira, 1970; Escandell, Marrero, \& Rubio, 1999; Latiesa, 1986; Latiesa, 1992; Salvador \& García-Valcárcel, 1989). More recent studies conducted in different Spanish universities search and analyze the main dropout causes in the University of Sevilla (Guerrero-Casas, Hinojosa-Ramos, Hiraldo, del Carmen, \& Ordaz-Sanz, 2014). Cabrera, Bethencourt, Pérez, and Afonso (2006) make a general analysis of this problematic phenomenon. Consejero, García, Ibañez, and Ortega (2008) aim to identify and describe some psychosocial causes that affect the process of permanence at the University of Cadiz. There are other several studies in Spain regarding this topic (Araque, Roldán, \& Salguero, 2009; Cabrera, Bethencourt, González, \& Álvarez, 2006; Cobo, 2010; Corominas-Rovira, 2001; González, Álvarez, Bethencourth, \& Cabrera, 2005; Lassibille \& Navarro-Gómez, 2008; Rodríguez-Marín, 2004; Ruè-Domingo, 2014; Sposetti \& Echeverría, 2000).

The study of this trend has extended beyond Spain. A European study made by the European Commission in 2013 (Quinn, 2013) reflects how dropout rates affect different European countries as well as which students do not continue their higher education and why. A study in Copenhagen in 2013 by Rode et al. (Larsen, Sommersel, \& Larsen, 2013) evaluate the dropout phenomena at universities, its consequences and the politic and economic context of university dropout. Many other studies related to this topic can be found in (Arulampalam, Naylor, \& Smith, 2004; Chen, 2008; Davies, Elias, \& Britain, 2003; Glaesser, 2006; Heublein, 2014; Hovdhaugen \& Aamodt, 2009; Van den Berg \& Hofman, 2005; Wolter, Diem, \& Messer, 2014).

The aim of this article is to show the values of the dropout rates in Spain from different sources as well as to identify the different variables which influence this indicator. Futhermore, we will present some experimental cases from different Spanish universities and we will study the causes of this phenomenon. Finally, we will explain the measures implemented in order to face the growth of this worrying rate.

\section{Dropout Rate Definition}

The dropout rate appears as a quality indicator in many models of university assessment (MEC: Catalogue of the Spanish public university system indicators). The Ministry of Education, Culture and Sports (Spanish Government. Ministerio de Educación, Cultura y Deporte., 2013) explains that when considering this indicator, we must make a distinction between study dropout rate, study exchange rate and university system dropout rate. These terms frequently lead to confusion or contradiction in some studies as its definition must be clearly formalized. The study dropout refers to those students who have quit a particular teaching program. This includes those students who have left the university system, who have changed their studies or who have left Spain to further studies. The study exchange rate represents the percentage of students whose study has changed. This percentage is also included in the dropout rate. Finally, the Spanish university system (SUE) dropout rate measures the percentage of students that have left the university system before graduation.

\section{Dropout Rate Value in Spain and Main Influence Factors}

The Ministry of Education, Culture and Sport collects in its report "Basic data of the Spanish university system" (Spanish Government. Ministerio de Educación, Cultura y Deporte., 2013) different data about the dropout rate and the study exchange rate. The first indicator is calculated as the percentage of students that do not matriculate at a university during the two following years. The second rate is computed as the percentage of students that enroll in other studies in the next two years. For the 2009-2010 academic course, the dropout rate in Spain was $19 \%$ (one out of five students abandoned their studies that year) while $7.1 \%$ of students decided to change the career they have started. The figures in the case of Galicia are not so alarming, the dropout rate and the study exchange rate stayed at $13.6 \%$ and $6.2 \%$ respectively, this means than one out of seven undergraduates do not continue their higher studies. The same study reflects that some factors affect this indicator such as whether the institution is public or private and the modality each university offers. This last factor is decisive. The students who choose to take distance courses are usually older than those who study at universities that do not offer this type of learning, and they usually possess another degree or diploma. The dropout rate in distant learning is much higher than in the other modality. The figure below shows the difference between indicators in these cases 
(Figure 1).

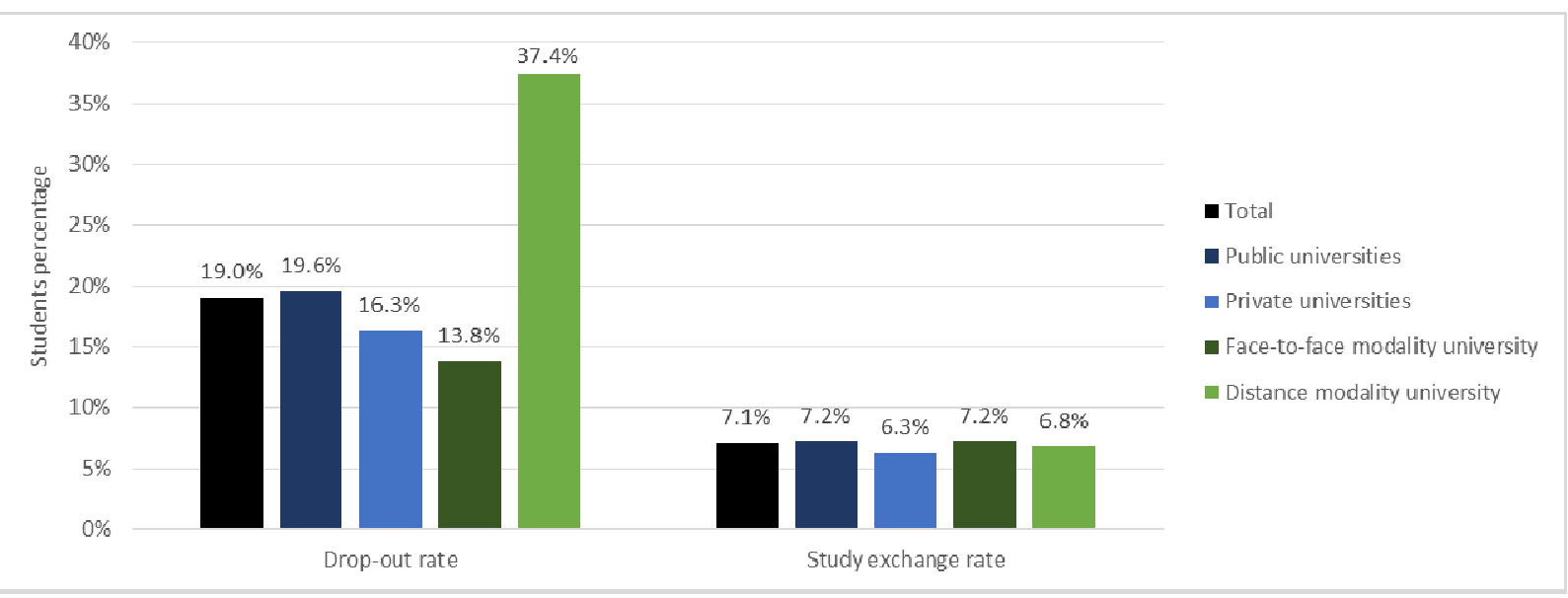

Figure 1. Dropout and study exchange rates depending on public, private and the modality of the universities in Spain in 2009/10

As we can see, the dropout rate is slightly lower in private universities in comparison with public universities, whereas a clear difference in this percentage is shown depending on the modality. One out three distance learning students does not continue their courses versus one out of fourteen face-to-face learning students. On the other hand, the study exchange rate does not experience large variations when these factors are studied.

According to the paper "Basic data of the Spanish university system" when analysing each academic discipline, it is observed that in Arts and Humanities the dropout rate is much higher, compared to the other disciplines. This value varies between $17 \%$ and $18.3 \%$ in most studies whereas in this category this percentage rises to $28.8 \%$. Figure 2 shows these values. The differences in the study change rate are not so significant, however in this particular rate the influence of vocation becomes very important. Vocational degrees such as Health Sciences, Engineering and Architecture present the lower rates while, on the contrary, these values are higher in Sciences.

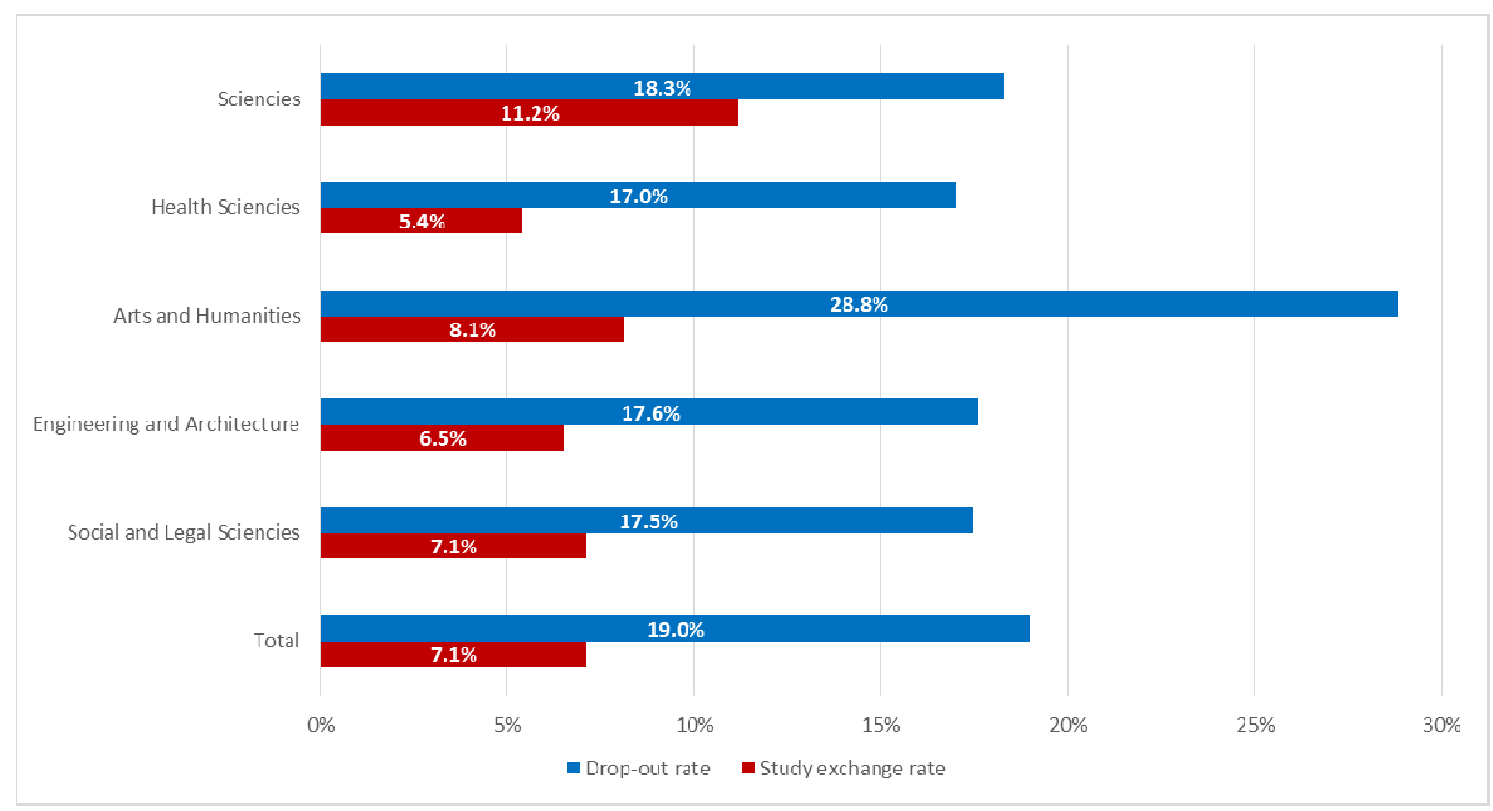

Figure 2. Drop-out and study exchange rates depending on different fields of study in Spain in 2009/10 
The regions with lower dropout rate in Spain are Navarre, Castile and Cantabria. On the contrary, the Balearic Islands and La Rioja have the higher rates. As it was mentioned before, the dropout rate and the study exchange rate in Galicia both stay at $13.6 \%$ and $6.2 \%$ respectively. This figures are both lower than the average rates in Spain. See Figure 3.

The report published by the Ministry of Education, Culture and Sport (Spanish Government. Ministerio de Educación, Cultura y Deporte., 2013) also provides information about how the admission score affects the dropout rate. Students with higher admission scores have low dropout rates and vice versa. The grading system is Spain is ranked from 0 to 10 points, being 5 the minimum qualification to pass a subject. Qualifications from 5 to 10 are considered passed, being 10 the best possible mark. Students with admission scores between 5 and 5.5 have a dropout rate of $19.8 \%$. This percentage is reduced to $7.3 \%$ for those students with the highest admission marks. The same trend can be seen in the study exchange rate.

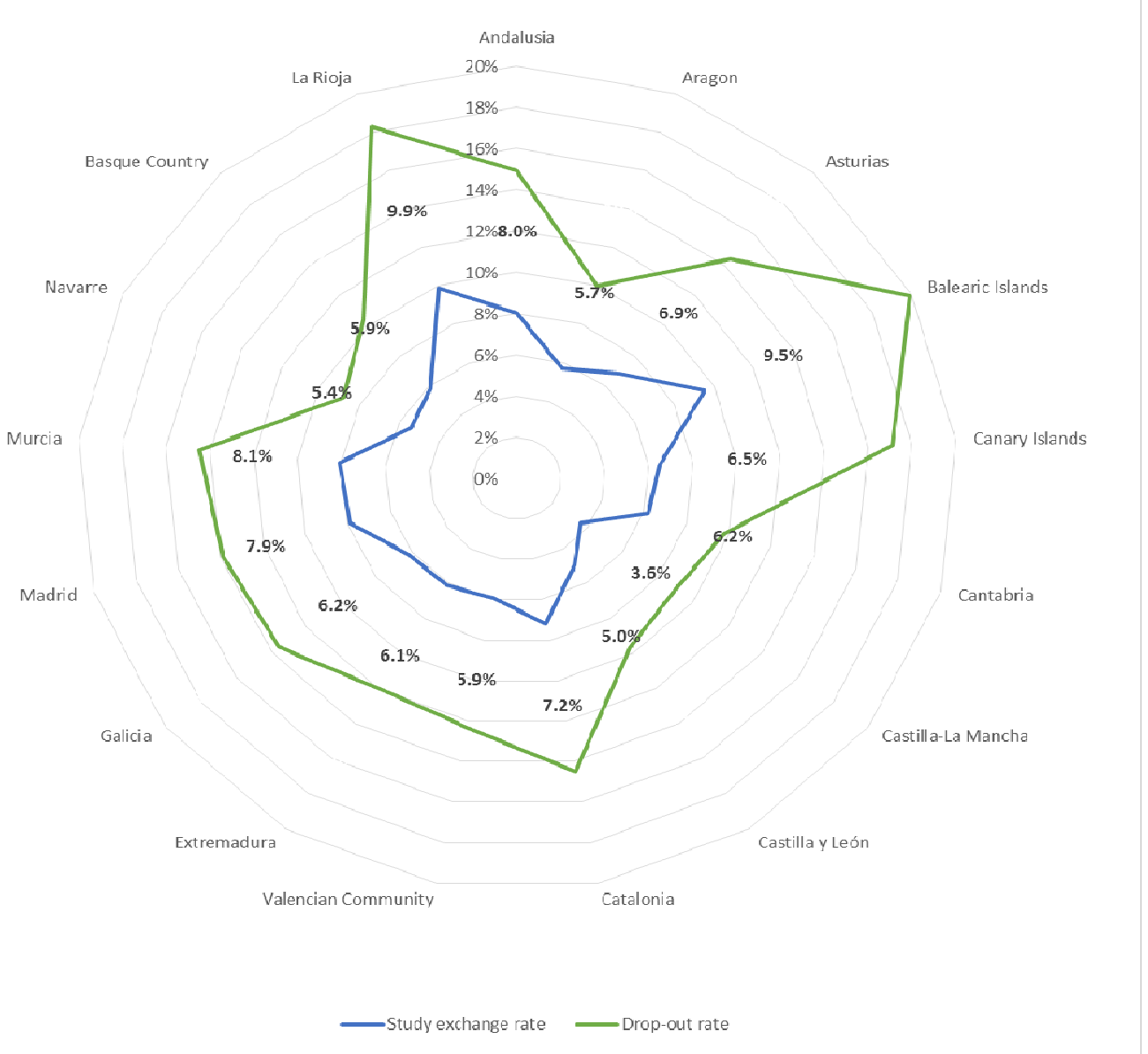

Figure 3. Drop-out and study exchange rates depending on the region in Spain in 2009/10

Until the 2011/12 academic course, there was not a minimum grade to get scholarships. Nowadays, the requirements to receive a study grant in Spain are increasing, due to this fact, more students were not able to obtain a scholarship. This fact also affects the dropout rates. Dropout rates are slightly lower for those students who get a grant. During the academic course 2009/2010, the percentage of scholarship students who abandon their education or who choose another degree is lower than the total percentage. According to the Spanish Ministry of Education, Culture and Sport, in this year the dropout rate and the study exchange rate for these students were $13.5 \%$ and $7 \%$ respectively (19\% and $7.1 \%$ for all the students enrolled in the same course).

Other higher studies, such as masters, have also high dropout rates. The report "Basic data of the Spanish university system" (Spanish Government. Ministerio de Educación, Cultura y Deporte., 2013) states that in this kind of higher education the dropout rate stands at $15.6 \%$ while the study exchange rate stands at $3.5 \%$ for the 
2009/2010 academic course (Figure 4), both values are lower than the degree dropout rate. It can also be observed that the study exchange rate is halved. Following this criteria, for the same course, private universities have a higher dropout than public universities. As in degree studies, the distance modality experiments have again the greater dropout rates. The study exchange rates remains constant for the most part but it experiments an increase when the university offers distance learning courses.

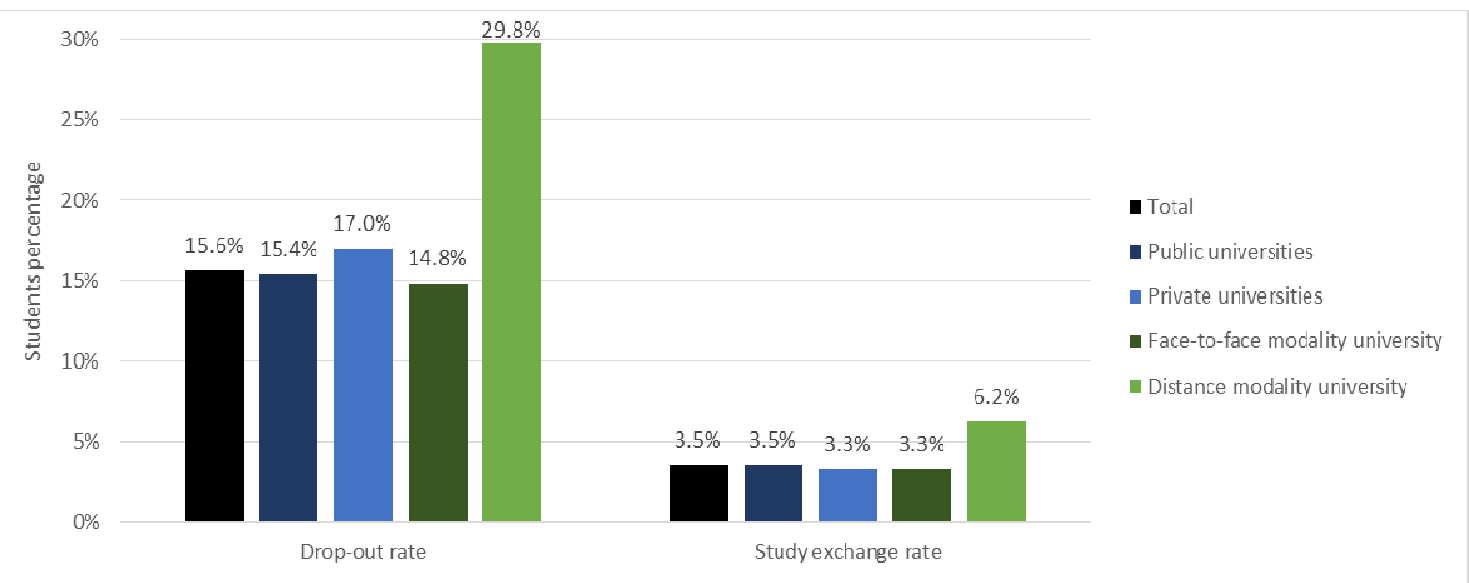

Figure 4. Masters dropout and study exchange rates depending on public, private and the modality of the universities in Spain in 2009/10

Masters in Engineering, Architecture and Arts and Humanities show the higher dropout rates. On the contrary, the best values are found in Social and Legal Sciences during the same year, both for dropout and study exchange rates. Masters in Health Sciences show the greatest study exchange rates (Figure 5)

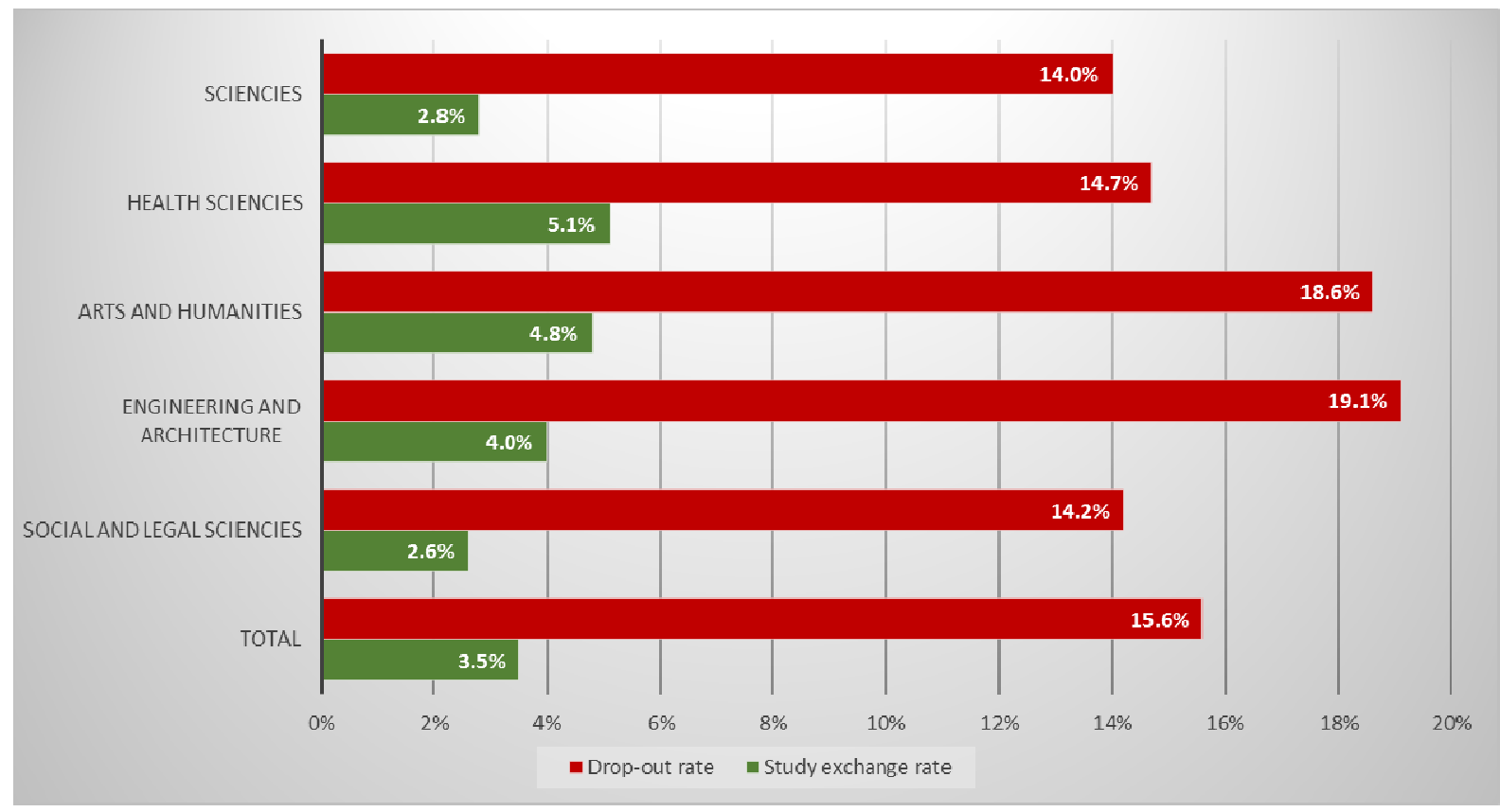

Figure 5. Master dropout and study exchange rates depending on different fields of study in Spain in 2009/10

In addition, the Spanish Ministry of Education, Culture and Sport presents in its report (Spanish Government. Ministerio de Educación, Cultura y Deporte, 2013) a study about how the age of students enrolled in a master affects to both dropout rate and study exchange rate (Figure 6). The dropout rate increases as the age of the 
master students does while the study exchange rate is not affected by this factor.

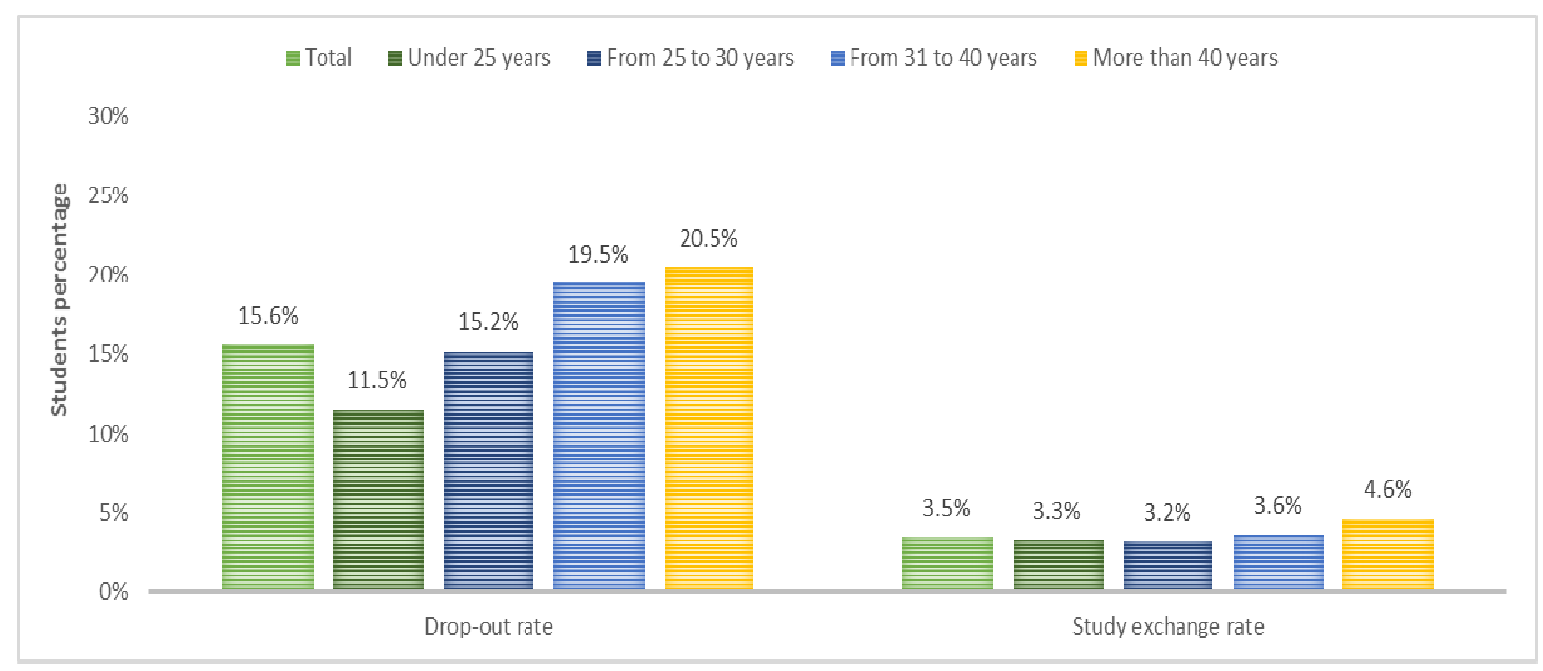

Figure 6. Master dropout and study exchange rates depending on different ages of the enrolled students in Spain in $2009 / 10$

The crisis in Spain is another decisive factor that affects the education system. Based on the data that appeared in the CYD report (Fundación CYD, 2013), a report that analyses different sources like Eurostat, the Organization for Economic Cooperation and Development OECD, and Education at Glance 2013; Spain, unlike other developing countries, has barely registered a growth in higher education enrolment between the years 2001 and 2011. During the years corresponding to the crisis period (2007-2011) the number of Spanish students that enrolled in a university course increased due to joblessness. Before this period, between 2001 and 2007, during the economic expansion period the job creation rate was greater than the average employment rate of the European Union. Dropout rates during this period increased because higher education was not essential to find a job. The rise in the price of tuition as well as the crisis provoked once more a fall in the number of Spanish university students during the 2012/2013 academic course according to the CYD report (Fundación CYD, 2013).

We must also take into account that in Spain the unemployment rate peaked since 2007 due to the crisis that affected the country. University education directly influences the unemployment rate. However, research undertaken by the Spanish Ministry of Education, Culture and Sport shows that this influence has been uneven depending on the level of education reached. In its report "Basic data of the Spanish university system" (Spanish Government. Ministerio de Educación, Cultura y Deporte., 2013) total values for this rate from $8.3 \%$ in 2007 to $25 \%$ in 2012 are presented. This growth has been lower for people with higher education, from $5.4 \%$ in 2007 to $15.2 \%$ in 2012 , and even lower in the case of the population with doctorate, from $2.7 \%$ in 2007 to $4.7 \%$ in 2012 . Figure 7 shows the correlation between unemployment rates and education levels. 


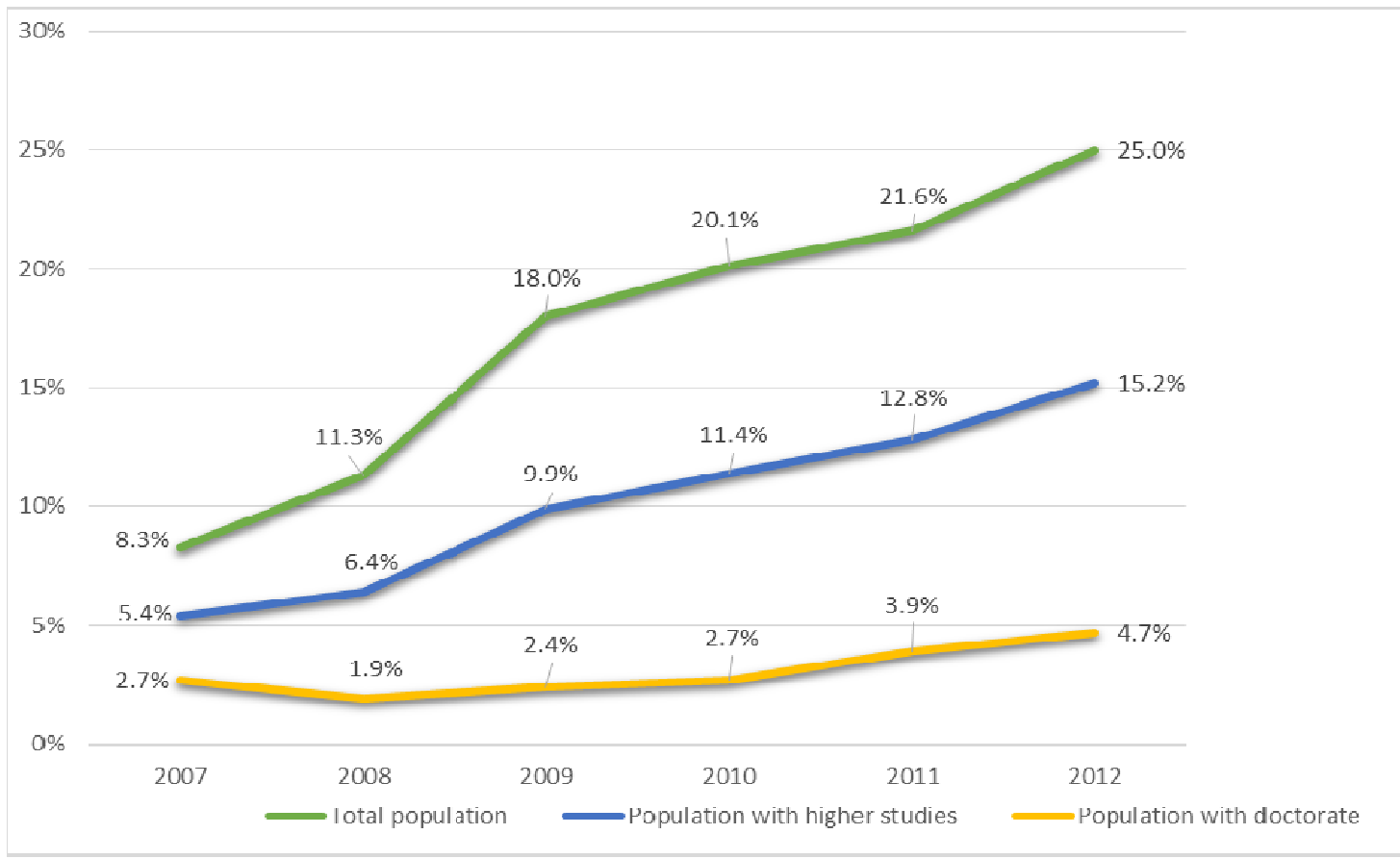

Figure 7. Correlation between unemployment rates and education levels in Spain from 2007 to 2012

Underemployment, understood as a worker with university studies who works in a lower professional category to which it would correspond, can be seen as a factor that favours the university dropout. According to a report from the BBVA research (García, 2011), around 35\% of graduates in Spain since 1992 to 2010 are working in jobs that require low qualification. In comparison with other countries, Spain presents the highest rate of underemployment. Figure 8 shows these data from the BBVA research report. The same report notes that this fact is more prominent among the population between 25 and 29 years of age. Once again, this rate is much higher in Spain than in other countries and reaches almost $45 \%$ of the population. Figure 9 shows these data.

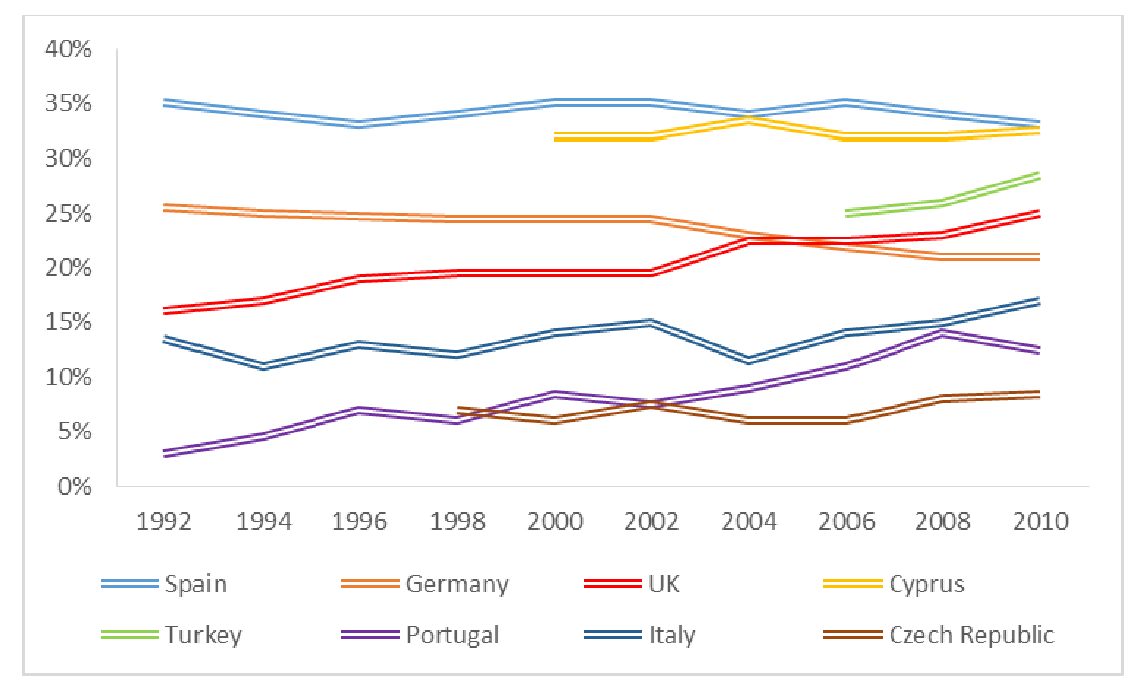

Figure 8. Underemployment percentage from 1992 to 2010 


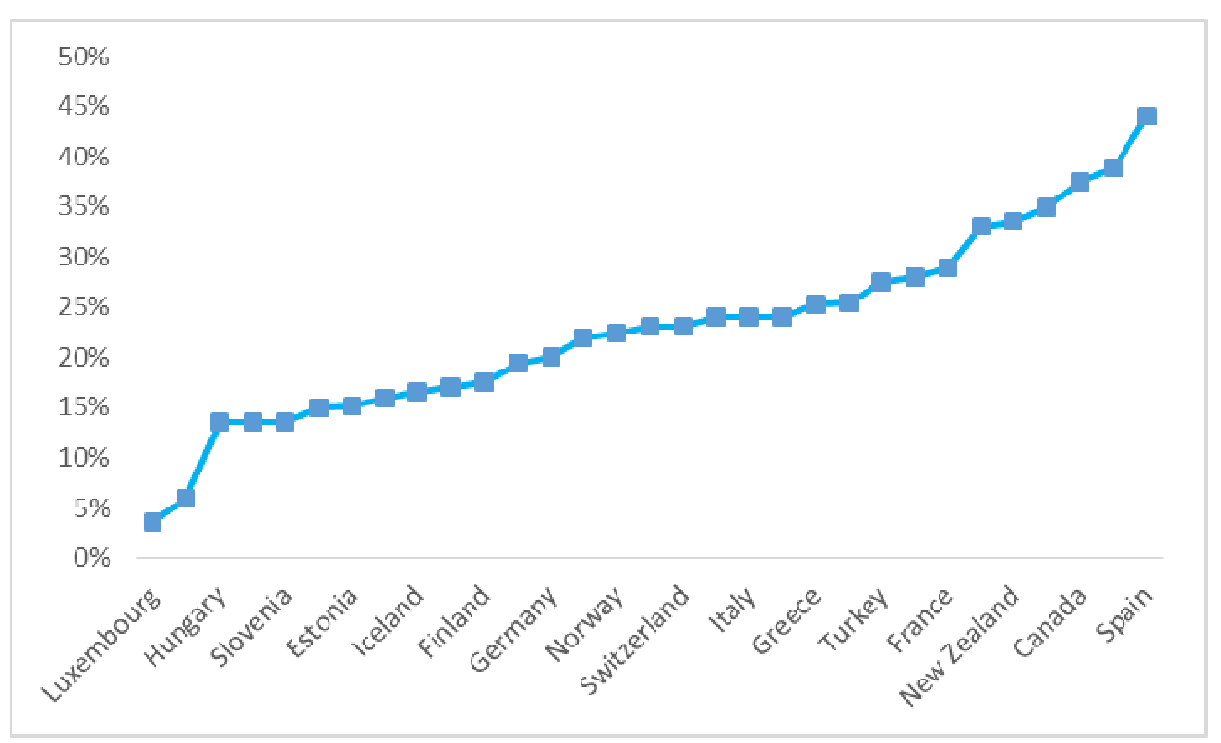

Figure 9. Underemployment percentage in population between 25 and 29 years old in 2007

Despite the low volume of data on dropout rates in Spain, the Spanish University Rectors' Conference (CRUE) provided the dropout rates of public Spanish universities for the academic years 2006/2007, 2008/2009 and 2010/2011 (Hernández, 2008; Michavila, 2013). In order to analyze the progression that this indicator experiments over the time, below we present some graphs that compare the data from the years 2006/2007, $2008 / 2009$ and 2009/2010. Figure 10 shows the difference in dropout rates in face-to-face learning universities, distance learning universities and public universities in Spain in the mentioned years. As observed, this indicator has decreased although its value continues being considerably high. In face-to-face learning universities the dropout rate was $22.67 \%$ during the academic course $2006 / 2007,18.77 \%$ for the course $2008 / 2009$ and $13.8 \%$ for the course 2009/2010. In the case of distance learning universities these values were $55.2 \%, 51.36 \%$ and $37.4 \%$ during 2006/2007, 2008/2009 and 2009/2010 respectively. The total dropout rate for Spanish public universities stayed at 38.93\% (2006/2007), 35.07\% (2008/2009) and 19.6\% (2009/2010).

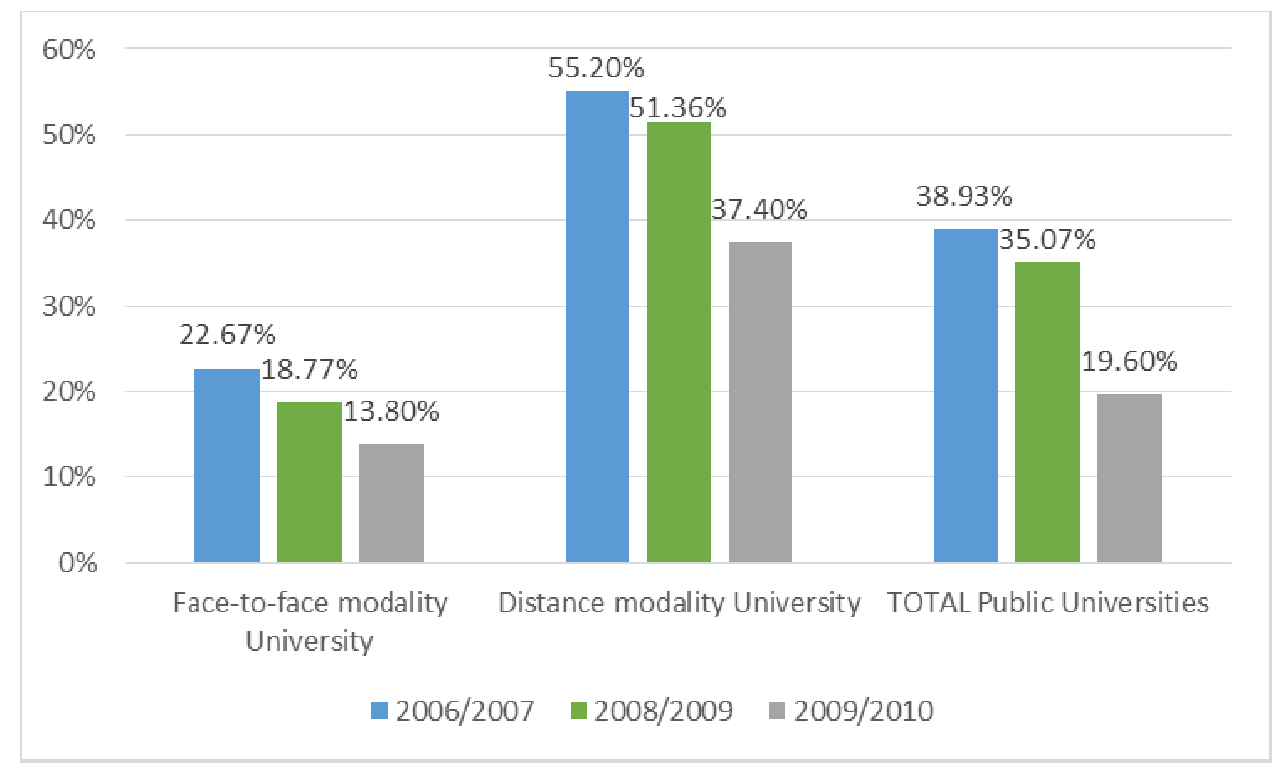

Figure 10. Progression of dropout rates for Spanish public universities in 2006/2007, 2008/2009 and 2009/2010 
A comparison between the different fields of study during this period of time is also analysed. In Social and Legal Sciences as well as in Sciences and Engineering and Architecture, according to the data provided by the Spanish University Rectors' Conference (CRUE) for the 2006/2007 and 2008/2009 academic courses (Hernández, 2008) and the Spanish Ministry of Education, Culture and Sport for academic year 2009/2010 (Spanish Government. Ministerio de Educación, Cultura y Deporte., 2013), the dropout rates have decreased. On the other hand, in the case of Arts and Humanities and Health Sciences, this indicator has decreased from the academic year 2006/2007 to 2008/2009 whereas for the course 2009/2010 its value has increased again. Figure 11 represents these rates.

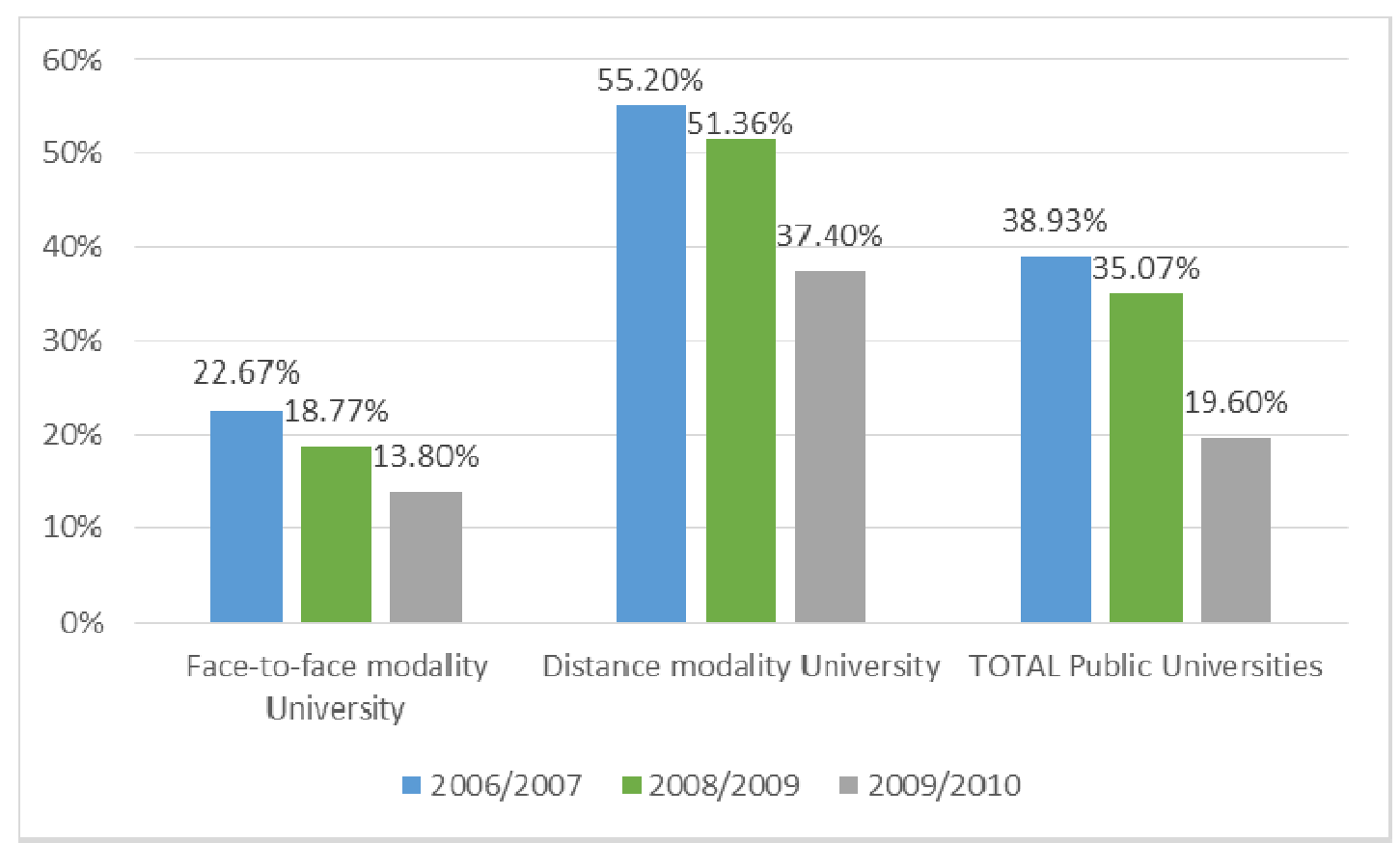

Figure 11. Progression of dropout rates depending on different fields of study in Spain in 2006/2007, 2008/2009 and 2009/2010

In most of the Spanish autonomous communities, the dropout rates have slightly decreased as shown in Figure 12. Only in La Rioja, Castilla-la-Mancha and Balearic Islands this trend is not met. 


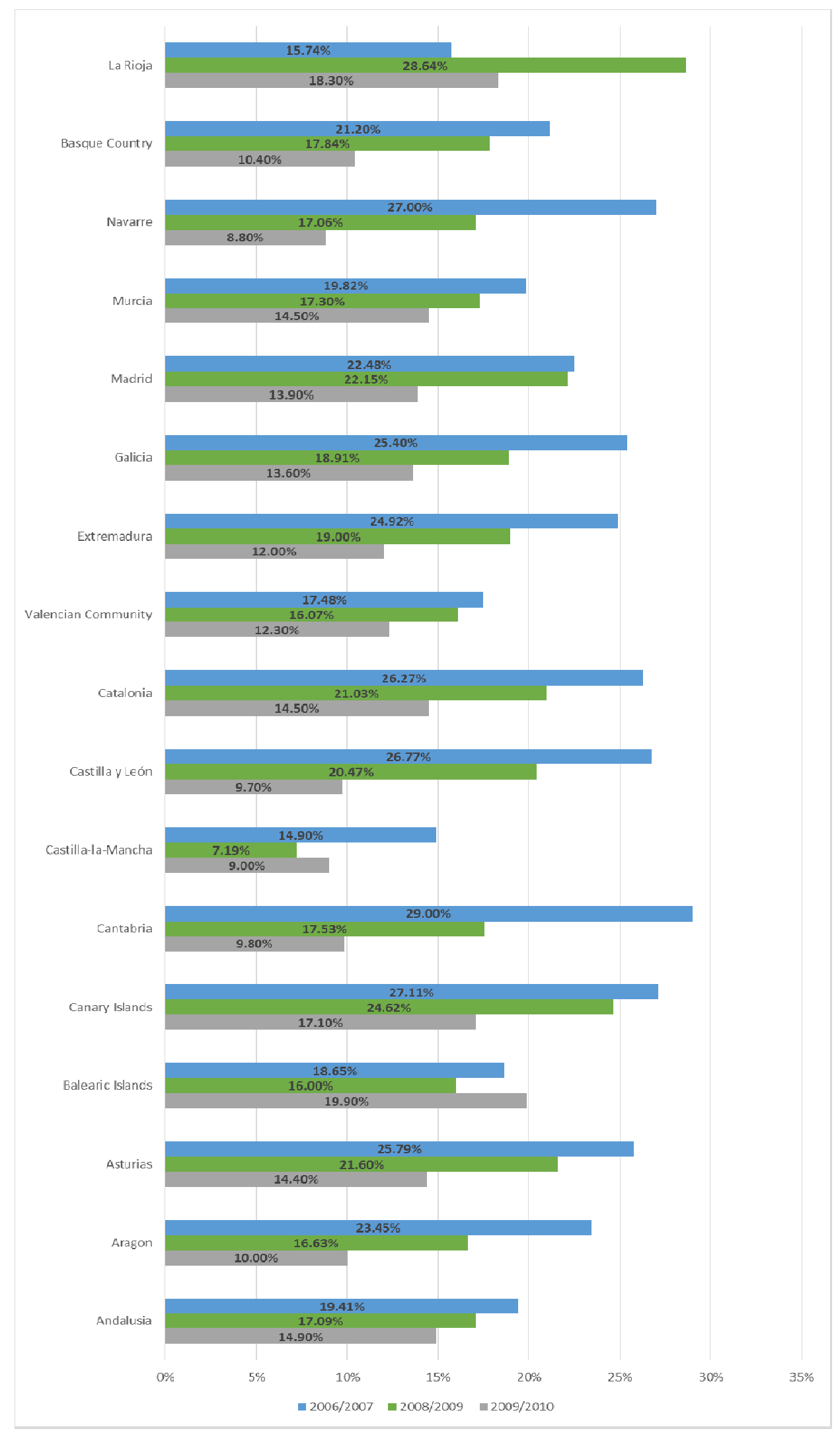

Figure 12. Progression of dropout rates depending on the region in Spain in 2006/2007, 2008/2009 and $2009 / 2010$ 
It should also be noted the great economic impact of university failure. A study by BBVA research (de la Fuente Moreno, \& Serrano, 2013) shows that the dropout rates generates a cost of 5,772 euros per year and per student. This research notes that this impact is even greater if the student drops out in the first cycle. In this case the figure rose to 7,120 euros per year and per student. These data are taken from a report authored by (de la Fuente Moreno \& Serrano, 2013) in which the economic impact of the educational failure is analysed. In order to calculate these costs, de la Fuente et al. compute the total costs of a school place with and without failure. In this way, the cost of the school failure is calculated as the difference. According to this report, university failure costs twice than in both FP I and FP II studies (the first and second phases of vocational training), and this amount is even higher in comparison with secondary studies. As mentioned before, these costs will vary depending on the university course. Costs decrease as the student progress in his studies. As we have mentioned above, this explains the figure of 7,120 euros per year and per student for the first cycle. This figure is reduced to 6,224 euros per year and per student in the case of the second cycle and to 3,974 euros per year and per student in a doctorate (Figure 13).

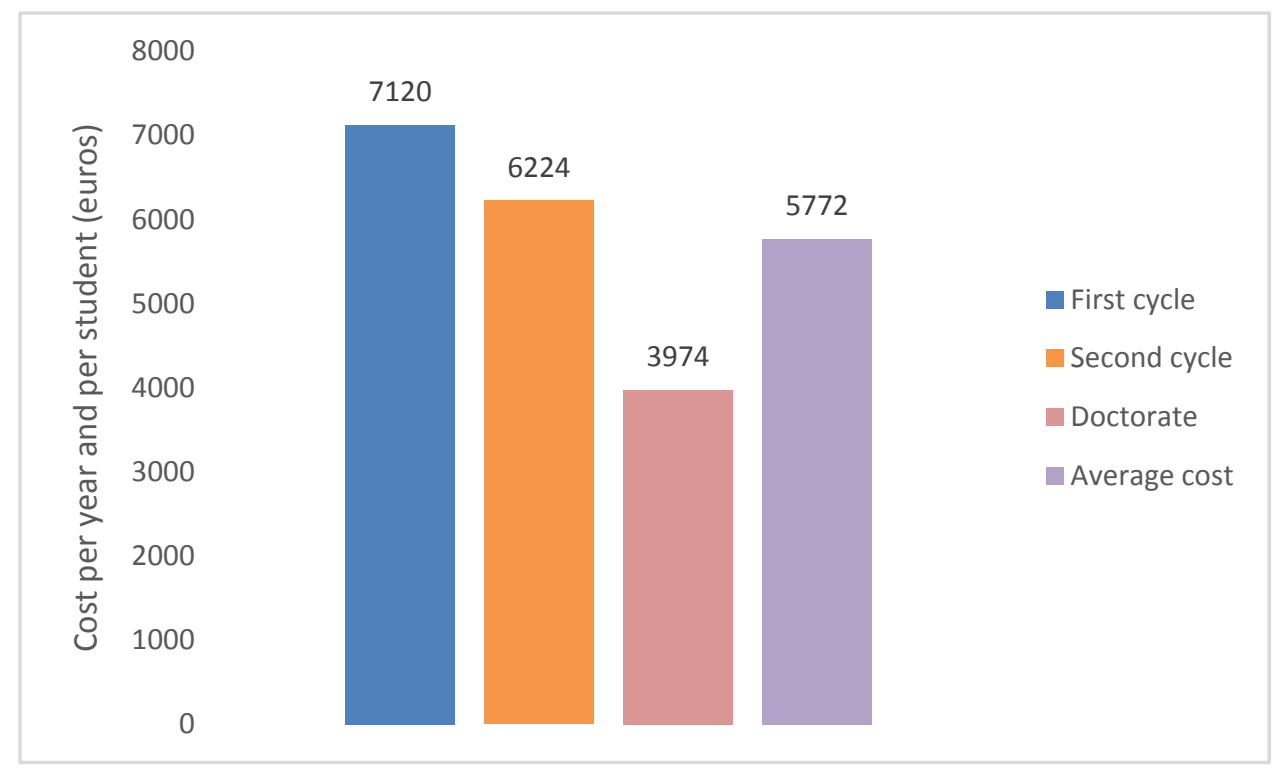

Figure 13. University dropout cost per year and per student

\section{Particular Case of Universities in Galicia}

The particulate case of the universities in the Autonomous Community of Galicia is also analysed in this report. According to the SIIU (Integrated University Information System), 66,594 students between 18 and 24 years of age were registered in a degree, a $1^{\circ}$ and $2^{\circ}$ cycle or in a master in Galicia for the 2012/2013 academic course. This value represents a net enrolment ratio in higher education of $25.8 \%$ computed as the number of enrolled students between 18 and 24 in higher education divided by the total population in the same interval of age. Compared to the total value of $28.6 \%$ in Spain, Galicia is slightly below the Spanish average. Figure 14 shows how these 66,594 students are divided. 


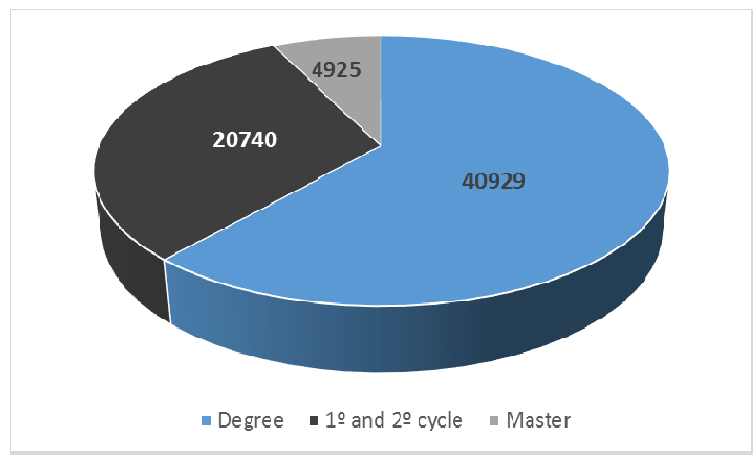

Figure 14. Number of students enrolled in a degree, a $1^{\circ}$ and $2^{\circ}$ cycle or a master in Galicia in 2012/2013

Galicia has three universities: University of A Coruña, University of Santiago de Compostela and University of Vigo. The University of A Coruña was created in 1989 and it is structured in two campus: A Coruña and Ferrol. The University of Santiago de Compostela is one of the ancient universities in Europe. It is organized into two campuses: Compostela and Lugo. The University of Vigo's campus is campus spread over three cities: Ourense, Pontevedra and Vigo.

The latest data provided by the Spanish Ministry of Education, Culture and Sport for the course 2009/2010 indicates a dropout rate in Galicia of $13.6 \%$ and a study exchange rate of $6.2 \%$. Both values are lower than the total values achieved in Spain, 19\% and 7.1\% respectively (Figure 15).

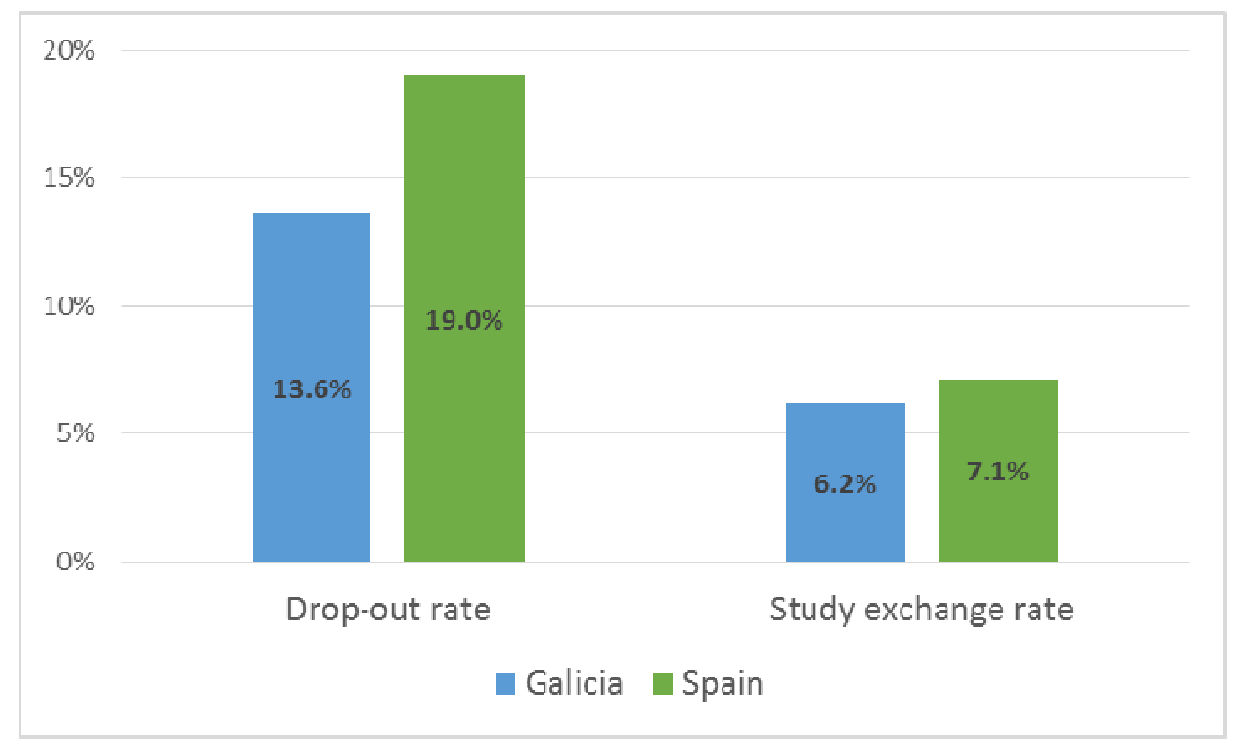

Figure 15. Degree dropout and study exchange rate in Galicia and Spain in the course 2009/2010

In the case of Master studies, both the dropout rate and the study exchange rate are also lower in Galicia than in Spain. The Master dropout rate in Galicia for the same year is $10.7 \%$ whereas in Spain this value stayed at $15.6 \%$. The exchage rate is lower in master studies: $1.6 \%$ in Galicia and 3.5\% in Spain (Figure 16). 


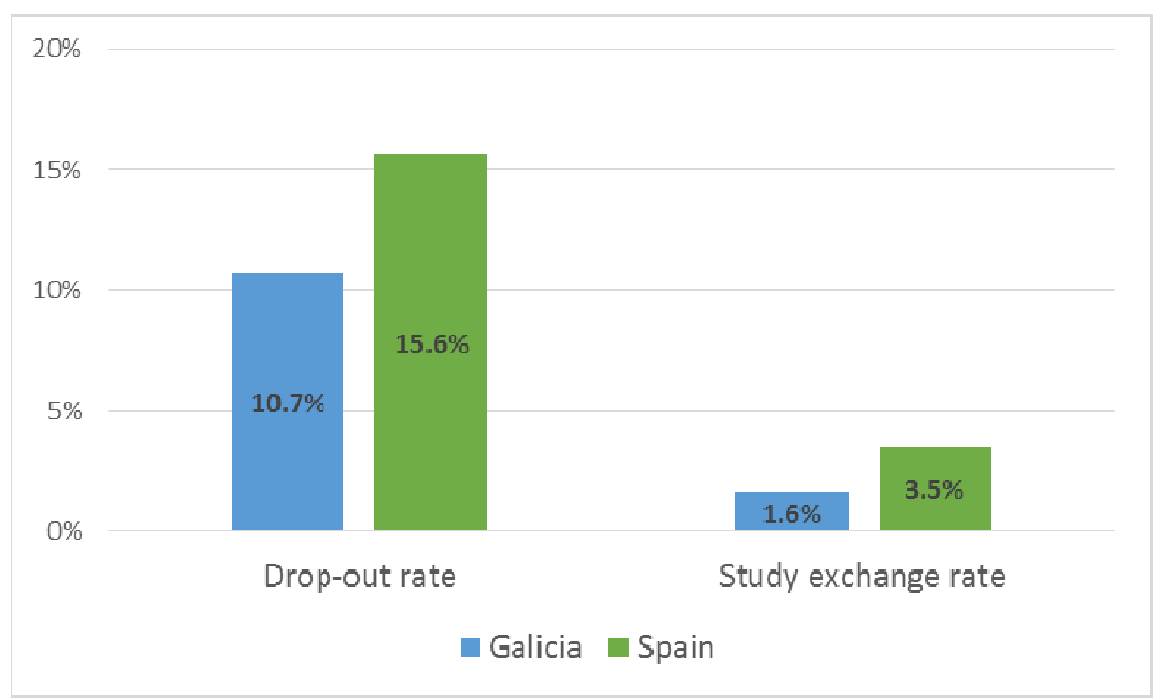

Figure 16. Master dropout and study exchange rate in Galicia and Spain in the course 2009/2010

The data presented by the Spanish University Rectors' Conference (CRUE) for the courses 2006/2007 and 2008/2009 (Hernández, 2008) allows us to study more closely the dropout rates in public and face-to-face universities of Galicia, particularly for each of the three universities: A Coruña, Santiago and Vigo. The following figures (Figure 17 and Figure 18) represent these data.

In the course 2006/2007, the total dropout rate (25.4\%) in Galicia was higher than in Spain $(22.67 \%)$. This rate was higher in all the fields of study except in Engineering and Architecture. The three universities of Galicia present similar values, although the University of Vigo has the best results (that is, the lower dropout rates), except in Arts and Humanities in which Vigo has the highest dropout rate.

In the academic course 2008/2009, the dropout rates in Galicia and in Spain have decreased compared to the course 2006/2007. Galicia still has a higher value (18.91\%) than Spain (18.77\%), although the difference was close to zero. In this academic year, the University of A Coruña presents the best results, except in Health Sciences in which the University of Vigo has the lowest dropout rate.

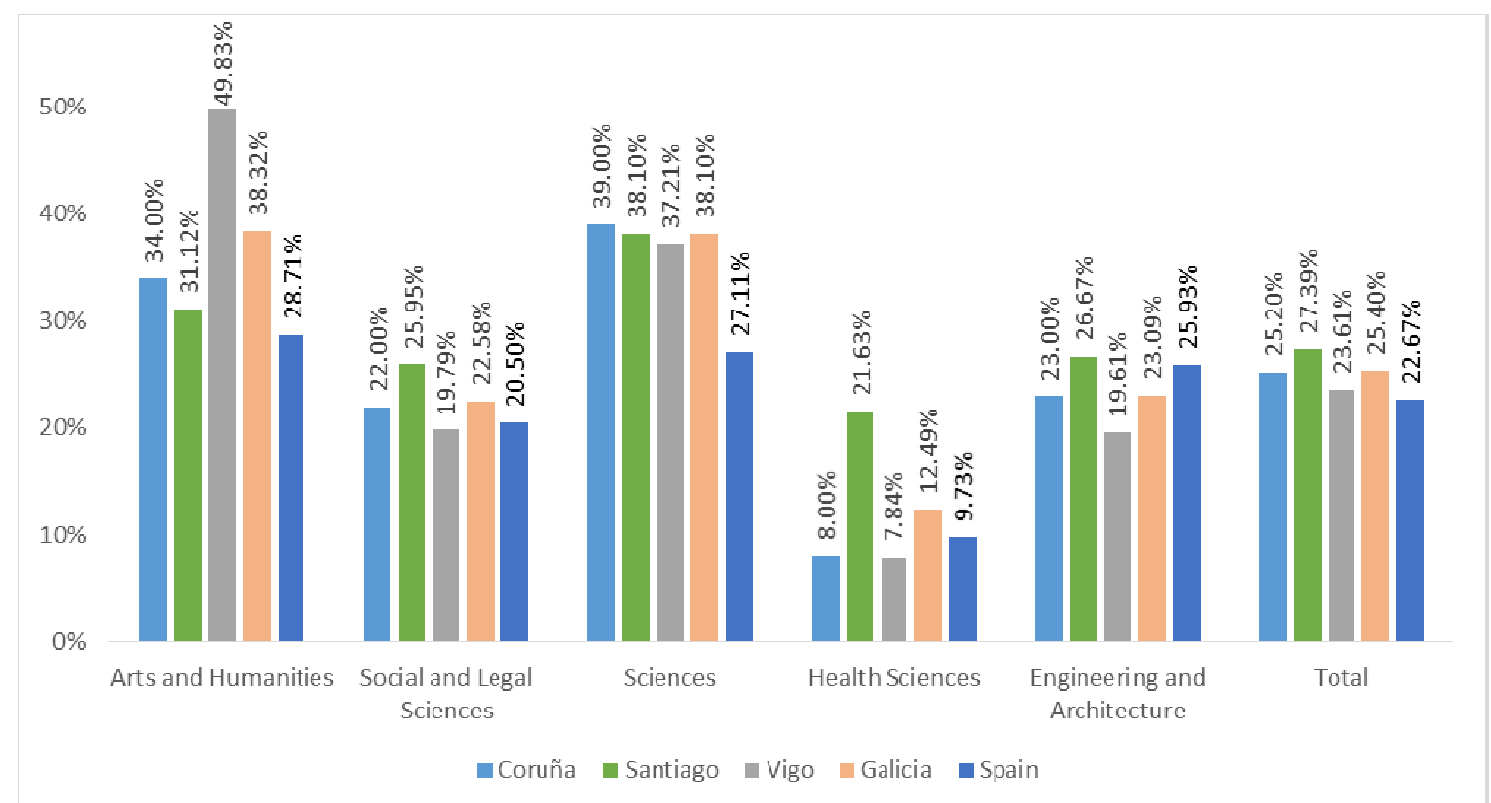

Figure 17. Dropout rates in A Coruña, Santiago, Vigo, Galicia and Spain depending on the field of study for the course 2006/2007 


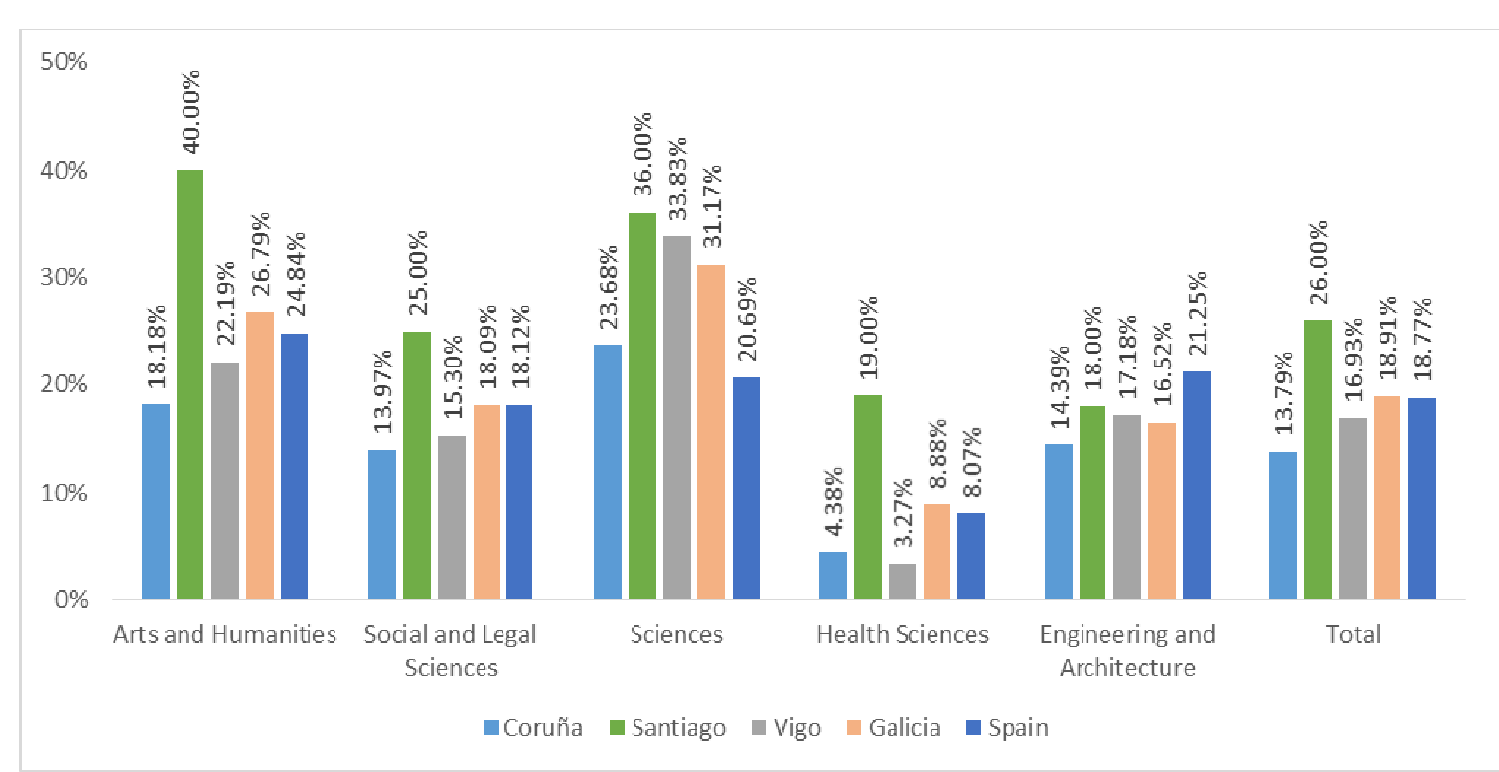

Figure 18. Dropout rates in A Coruña, Santiago, Vigo, Galicia and Spain depending on the field of study FOR the course 2008/2009

\section{Causes of Student Dropout}

The analysis of the reasons that lead students to abandon their higher education studies is essential to understand and to be able to deal with this phenomenon. There have been many studies that investigate the causes of these high dropout rates.

Cabrera et al. (2006) identify six main variables of dropping out (Figure 19). The first refers to factors of psycho educational nature. These factors are considered the most significant and they have been identified in numerous studies. The university environment and the academic self-efficacy also are among the causes for dropping out. In turn, Kirton (2003) indicated the following facts as variables that lead to a student dropping out of college: academic self-efficacy, educational values, and perception of the college environment, university support and attachment to peers. The second cause identified by Cabrera et al. is related to the evolutionary adaptation period. During those years, young people experience a vast amount of changes in their physical, emotional and social maturity: immaturity, identity establishment, emotions, personal conflicts...The third point refers to family variables. The strong pressure that many parents put on students regarding their vocational choices and their qualifications leads in most cases to dropping out. In relation with this last variable, family businesses and family responsibilities are another major obstacle. The fourth point concerned the economic variables. Due to the current economic crisis in Spain many families face financial difficulties. However, this issue is not the main problem. In Spain, grants are factors that help the students to avoid dropping out from college. If a student does not receive a scholarship, he may be forced to work to pay his studies, a situation that may lead to abandonment. Another important point is the institutional variable. A great responsibility is attached to teachers, not only to their teaching methods but also to their evaluation methods. Other features that may causes this situation are the characteristics of the studies and the academic resources; several investigations show that active learning has beneficial effects on the students' persistence versus passive learning. Finally, the social variables also play an important role. Despite the lack of research on the relation that these variables have with dropout rates, it is also worth taking into account some circumstances as the emergence of educational institutions which offer services in a much more suitable way and accessible to jobs, a close relation between the economic activity and what to teach and the high rates of unemployment among graduates which cause demotivation. 


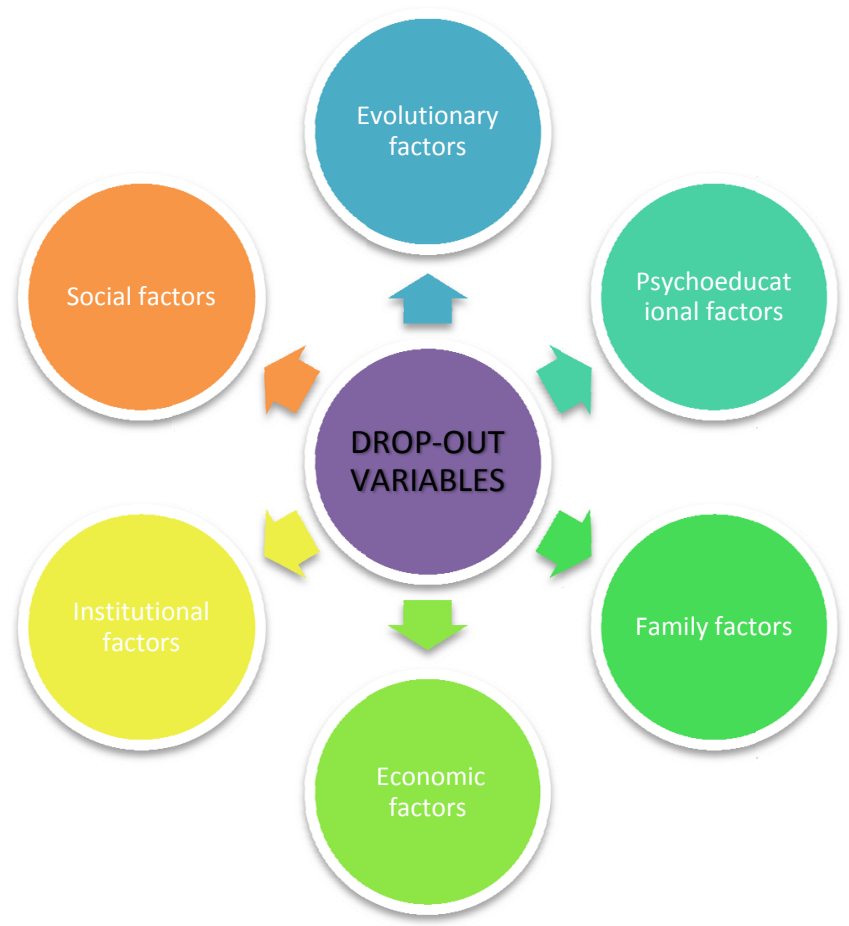

Figure 19. Main variables responsible of dropout rates

Some experimental studies (Consejero et al., 2008; Davies et al., 2003) carried out in different universities, investigated the dropout causes of students who had abandoned their studies. Based on these data, some of the specific reasons for dropping out are shown in the table below (Table 1).

Table 1. Some dropout motives of students who have abandoned their studies

\begin{tabular}{l}
\hline Dropout motives \\
\hline Entering the labor market \\
Incompatibility with work \\
Economic motives \\
Too theoretical studies \\
Dissatisfaction with teaching \\
Lack of mentoring \\
Insufficient prior knowledge or difficulty of overcoming studies \\
University environment \\
Failure to adapt to college life \\
Health problems \\
Lack of vocation \\
Language difficulties \\
Family difficulties \\
Uncertain professional future \\
Change of mind \\
Change of residence
\end{tabular}

A report from the Spanish Ministry of Education in 2010 (Cobo, 2010), states that the reasons for students dropping out of their studies can be grouped into three categories: social, economic and educational. This 
document refers, on the one hand, to individual circumstances and characteristics of students such as learning disabilities, health problems, low self-esteem...On the other hand, there are reasons related to the educational environment of the student. An unsatisfactory learning environment as well as a negative interaction with teachers influences the dropout rates. An inadequate support to students with educational or behavioral problems can lead into a premature dropout. Another factor indicated in this report is the effect of friends and classmates. The European Commission also notes that social reasons can favor this phenomenon. The family attitude plays a crucial role among the social reasons. Finally, this document refers to economic causes. As already mentioned, the high employment offer that did not require high levels of education until 2007 caused that many students decided not to continue with their education.

\section{Conclusions}

The existence of a high university dropout rate in Spain is undeniable. Data shows that approximately one out of five students drop out from college. On the other hand, study exchange rates have lower values. Public universities register greater dropout rates than private universities. A considerable difference is found depending on the learning modality: this indicator is much higher in distance learning universities than in face-to-face learning universities. The influence of vocation is also a factor that influences this rate, vocational degrees present lower rates. A study per region is also presented. Masters also have dropout rates although the values are lower compared to a degree. This rate increases at the same pace than the age of the enrolled students. The economic crisis is another that must be taken into account. During the economic expansion period (2001-2007) more students abandoned their studies than during the crisis period (2007-2011). This situation also affects unemployment rates due to the fact that higher education leads to lower unemployment rates. Galicia presented slightly higher dropout rates than Spain from 2006 to 2009; nevertheless during the 2009/2010 academic year this rate was lower. The reasons for dropout can be divided into six distinct factors: psycho educational, evolutionary, family, economic, institutional and social factors. The main drop-out motives are related, among others, to incompatibility with work, economy, university (environment, teachers and difficulties) and so on. According to the BBVA research, the dropout rate imposes a great cost on the entire economy reaching the sum of 5,772 euros per year and per student and exceeding the amount of 1,500 million Euros.

Due to the urgent need of reducing the dropout rate, the Ministry of Education developed an action plan to increase the number of young people enrolled in a higher education course; so that, consequently, Spain can redirect its economic growth model. In this way, a series of educational objectives were created for the decade 2010-2020. The action plan 2010/2011 is the starting point and it is based on some crucial programs such as improving the academic performance of students, modernization and flexibility of the education system, modernization and internationalization of universities, enhancing foreign languages learning, performing a strategic plan of Vocational Training, information and evaluation as factors to improve the education quality, teacher training and social dimension of education at all levels.

As it was already discussed above, in the case of Spain, for 2020 the dropout reduction has been fixed at $15 \%$ in the case of Spain and it is committed to increment by $44 \%$ the population between 30 and 34 years that complete higher education. In accordance with some international studies, it is expected that in the coming years only $15 \%$ of jobs will require people with no qualifications. This fact makes even more necessary the need to modernize our education system. The action plan developed seeks to create a flexible system that ensures excellence and equity. Research together with innovation will be some key points that should be enhanced during these years. The new education system should promote continuity in studies for most young people transferring them knowledge and will ensure that no student is excluded.

Universities also try to deal with this problematic phenomenon carrying out programs and strategies in order to increase the students' persistence. In order to achieve this, in Spain pre-university information and orientation actions, as well as educational and psychological support actions are conducted.

\section{References}

Araque, F., Roldán, C., \& Salguero, A. (2009). Factors influencing university drop out rates. Computers \& Education, 53(3), 563-574. http://dx.doi.org/10.1016/j.compedu.2009.03.013

Arulampalam, W., Naylor, R. A., \& Smith, J. P. (2004). A hazard model of the probability of medical school drop-out in the UK. Journal of the Royal Statistical Society: Series A (Statistics in Society), 167(1), 157-178. http://dx.doi.org/10.1046/j.0964-1998.2003.00717.x

Bendito, V. V., \& Altamira, A. I. (1970). Estudio sobre las tasas de abandono en la universidad central de barcelona. ICE De La Universidad De Barcelona. 
Cabrera, L., Bethencourt, J. T., González, M., \& Álvarez, P. (2006). Un estudio transversal retrospectivo sobre prolongación y abandono de estudios universitarios. RELIEVE, 12(1), 105-127. Retrieved from http://www.uv.es/RELIEVE/v12n1/RELIEVEv12n1_1.pdf

Cabrera, L., Bethencourt, J. T., Pérez, P. A., \& Afonso, M. G. (2006). El problema del abandono de los estudios universitarios. RELIEVE, 12(1). Retrieved from http://www.uv.es/RELIEVE/v12n2/RELIEVEv12n2_1.htm?iframe=true\&width $=80 \%$ \&height $=80 \%$

Chen, R. (2008). Financial aid and student dropout in higher education: A heterogeneous research approach. Higher education (pp. 209-239). Springer. http://dx.doi.org/10.1007/978-1-4020-6959-8_7

Cobo, R. (2010). El abandono temprano en la educación y la formación en españa. Revista De Educación, Número Extraordinario, $12, \quad 58-85 . \quad$ Retrieved from http://www.mecd.gob.es/revista-cee/pdf/n15-roca-cobo.pdf

Consejero, E., García, C., Ibañez, C., \& Ortega, F. (2008). Factores psicosociales relacionados con el abandono temporal académico de estudiantes en la educación superior. International Journal of Developmental and $\begin{array}{lllll}\text { Educational } & \text { Psychology, } & 2(1), & 227-236 . & \text { Retrieved }\end{array}$ http://infad.eu/RevistaINFAD/2008/n1/volumen2/INFAD_010220_227-236.pdf

Corominas-Rovira, E. (2001). La transición de los estudios universitarios. abandono o cambio en el primer año de universidad. Revista De Investigación Educativa, 19(1).

Council of Ministers of Spain. (2010). Objetivos de la educación para la década 2010-2020. plan de acción 2010-2011. Retrieved from http://www.mecd.gob.es/dms-static/a792d6ac-55fc-474c-bc4f-8c5204e8953a/ 2011-objetivos-educacion-decada-2010-pdf.pdf

Davies, R., Elias, P., \& Britain, G. (2003). Dropping out: A study of early leavers from higher education. Department for Education and Skills. Queens printer: London.

De la Fuente Moreno, A., \& Serrano, J. F. J. (2013). La rentabilidad privada y fiscal de la educación en españa y sus regiones. Moneda Y Crédito, 235, 179-246. Retrieved from http://documentos.fedea.net/pubs/dt/2011/dt-2011-11.pdf

Escandell, O., Marrero, G., \& Rubio, F. (1999). El abandono de los estudiantes en la universidad de las palmas de gran canaria: Sus causas, propuestas de estrategias para su disminución. Revista Electrónica Interuniversitaria De Formación Del Profesorado, 2(1), 369-399.

Fundación CYD. (2013). La universidad en españa.Oferta y demanda universitaria. Retrieved from http://www.fundacioncyd.org/images/informeCyd/2012/Cap1_ICYD2012.pdf

García, J. R. (2011). Desempleo juvenil en españa: Causas y soluciones. Madrid: BBVA Research. Retrieved from https://www.bbvaresearch.com/KETD/fbin/mult/WP_1130_tcm346-270043.pdf?ts=2152012

Glaesser, J. (2006). Dropping out of further education: A fresh start? findings from a german longitudinal study. Journal of Vocational Education and Training, 58(1), 83-97. http://dx.doi.org/10.1080/13636820600591743

González, M., Álvarez, P., Bethencourth, J., \& Cabrera, L. (2005). Incidencia de las variables del sujeto en el abandono universitario: Un estudio en la universidad de la laguna. International Conference, Careers Context: New Challenges and Tasks for Guidance and Counselling, Lisboa.

Guerrero-Casas, F. M., Hinojosa-Ramos, M. Á, Hiraldo, M., del Carmen, M., \& Ordaz-Sanz, J. A. (2014). Análisis de las causas de abandono académico de los estudios de una facultad de ciencias empresariales. Retrieved from http://www.asepelt.org/ficheros/File/Anales/2003\%20-\%20Almeria/asepeltPDF/168.PDF

Hernández, J. (2008). La universidad española en cifras. Información académica, productiva y financiera de las universidades españolas. Indicadores universitarios. Curso académico 2006/2007. Retrieved from http://www.oei.es/salactsi/UEC2008.pdf

Heublein, U. (2014). Student drop-out from german higher education institutions. European Journal of Education, 49(4), 497-513. http://dx.doi.org/10.1111/ejed.12097

Hovdhaugen, E., \& Aamodt, P. O. (2009). Learning environment: Relevant or not to students' decision to leave university? Quality in Higher Education, 15(2), 177-189. http://dx.doi.org/10.1080/13538320902995808

Kirton, M. J. (2003). Transitional factors influencing the academic persistence of first-semester undergraduate freshmen. UMI.

Larsen, M. R., Sommersel, H. B., \& Larsen, M. S. (2013). Evidence on Dropout Phenomena at Universities. 
Retrieved from http://edu.au.dk/fileadmin/edu/Udgivelser/Clearinghouse/Review/Evidence_on_dropout_ from_universities_brief_version.pdf

Lassibille, G., \& Navarro-Gómez, L. (2008). Why do higher education students drop out? Evidence from Spain. Education Economics, 16(1), 89-105. http://dx.doi.org/10.1080/09645290701523267

Latiesa, M. (1986). Demanda de educación superior y rendimiento académico en la universidad: Comunicaciones presentadas a las jornadas internacionales sobre demanda de educación superior. Centro Nacional de Investigación y Documentación Educativa.

Latiesa, M. (1992). La deserción universitaria. CIS, Madrid.GIROUX, H. (1992): Teoría y Resistencia en Educación.Siglo XXI Editores, Madrid.

Michavila, F. (2013). La universidad española en cifras 2012. In Conferencia de Rectores de las Universidades Españolas (CRUE). Retrieved from http://www.crue.org/Publicaciones/Documents/UEC/LA UNIVERSIDAD_ESPANOLA_EN_CIFRAS.pdf

Quinn, J. (2013). Drop-out and completion in higher education in Europe among students from under-represented groups. European commission. Retrieved from http://www.nesetweb.eu/sites/default/files /HE\%20Drop\%20out\%20AR\%20Final.pdf

Rodríguez-Marín, J. (2004). Tasas de éxito y fracaso académico universitario: Identificación y análisis de variables psicoeducativas relacionadas en una muestra de estudiantes españoles. Retrieved from http://www.orienta.org.mx/docencia/Docs/Sesion-7-8/Rodri\%CC\%81guez.pdf

Ruè-Domingo, J. (2014). El abandono universitario: Variables, marcos de referencia y políticas de calidad. REDU. Revista De Docencia Universitaria, 12(2), 281-306. Retrieved from http://red-u.net/redu/index.php/REDU/article/view/506

Salvador, L., \& García-Valcárcel, A. (1989). El rendimiento académico en la universidad de cantabria: Abandono y retraso en los estudios. Madrid, CIDE. Retrieved from http://redined.mecd.gob.es/xmlui/handle/11162/62223

Spanish Government. Ministerio de Educación, Cultura y Deporte. (2013). Datos básicos del sistema universitario español. curso 2013-2014. Retrieved from http://www.mecd.gob.es/dms/mecd/educacion$\mathrm{mecd} /$ areas-educacion/universidades/estadisticas-informes/datos-cifras/DATOS_CIFRAS_13_14.pdf

Sposetti, A., \& Echeverría, H. (2000). El factor educacional como causa potencial de la deserción en primer año de la universidad. Documento De Trabajo. Retrieved from http://www.unrc.edu.ar/publicar/cde/h21.htm

Tinto, V. (1982). Defining dropout: A matter of perspective. New Directions for Institutional Research, 1982(36), 3-15. http://dx.doi.org/10.1002/ir.37019823603

Tinto, V., \& Asociación Nacional de Universidades e Instituciones de Educación Superior (México). (1987). El abandono de los estudios superiores: Una nueva perspectiva de las causas del abandono y sutratamiento. UNAM; ANUIES.

Van den Berg, M., \& Hofman, W. (2005). Student success in university education: A multi-measurement study of the impact of student and faculty factors on study progress. Higher Education, 50(3), 413-446. http://dx.doi.org/10.1007/s10734-004-6361-1

Wolter, S. C., Diem, A., \& Messer, D. (2014). Drop-outs from Swiss universities: An empirical analysis of data on all students between 1975 and 2008. European Journal of Education, 49(4), 471-483. http://dx.doi.org/10.1111/ejed.12096

\section{Copyrights}

Copyright for this article is retained by the author(s), with first publication rights granted to the journal.

This is an open-access article distributed under the terms and conditions of the Creative Commons Attribution license (http://creativecommons.org/licenses/by/3.0/). 